\title{
The Effect of Organic Concentration on the Biochemical Degradation Characteristics of Hybrid Biological Reactor
}

\author{
Y. Zheng ${ }^{1}$, Y. T. Wang ${ }^{2}$, H.P. Chen ${ }^{3}$, Y.Y. Yang ${ }^{3 *}$ \\ ${ }^{1}$ Taiyuan Landscape and Architecture Design Institute, Taiyuan, Shanxi, China \\ ${ }^{2}$ Taiyuan urban-rural Planning and Design Institute, Taiyuan, Shanxi, China \\ ${ }^{3}$ School of Environmental Science and Engineering, Taiyuan University of Technology, Taiyuan, \\ Shanxi, China
}

Keywords: Hybrid biological reactor; Bio-film; Activated sludge; Organic matter; $\mathrm{C} / \mathrm{N}$

\begin{abstract}
The effects of $\mathrm{C} / \mathrm{N}$ on removal rate of $\mathrm{COD}$ and $\mathrm{NH}_{3}-\mathrm{N}$ of a continuous running hybrid biological reactor were discussed. The results showed that the removal rates of COD and $\mathrm{NH}_{3}-\mathrm{N}$ were both more than $90 \%$ in the normal condition. The bio-film played a key role in removing the $\mathrm{COD}$ and $\mathrm{NH}_{3}-\mathrm{N}$ in hybrid biological reactor. The sludge bulking occurred when $\mathrm{C} / \mathrm{N}$ is around 30 . The extremely high nitrification efficiency could be an early warning of the sludge bulking and the precursor time might be one or several days.
\end{abstract}

Till now, the most commonly adopted biological wastewater treatment methods are activated sludge process and bio-film process which both have good effects on the cleaning of wastewater. But activated sludge process does have many problems such as sludge bulking, sludge floatation, sludge washout and low adaptability for impact loads. On the other hand, the stuffed media surface is limited and which means limited volume load of bio-film reactor. Therefore, the hybrid biological reactor has become a new wastewater treatment method which has been studied more and more in recent years. It is an integration of activated sludge process and bio-film process. The characteristic is adding media into activated sludge aeration tank as carriers for microbes to grow on or attach on. The co-existence of bio-film and activated sludge improves the treatment efficiency and reliability. Compared with traditional activated sludge process, hybrid biological reactor has following advantages: (1) Hybrid biological system can accumulate more biomass than activated sludge system therefore has more efficient organic matter removal ability. (2) Filamentous bacteria are prone to attach on media which results in better settleability of activated sludge. This can prevent sludge bulking and improve the stability of running. (3) Because nitrifying bacteria attach on media and are resistant to be washed out, the nitrification efficiency will not be affected by the SRT and ultimately the denitrification ability is enhanced. These studies show that the hybrid biological reactor is an effective way to improve the organic matter removal ability.

An experiment was carried out in order to investigate the effect of organic matter concentration on the organic matter degradability of the hybrid biological system. In this experiment, the removal efficiencies of $\mathrm{COD}$ and $\mathrm{NH}_{3}-\mathrm{N}$ in hybrid biological reactor were studied by increasing organic matter concentration under continuous flow meanwhile limiting the $\mathrm{NH}_{3}-\mathrm{N}$ concentration of the influent in a certain range.

\section{Materials and Methods}

Equipments. The hybrid biological reactor is a cylindrical column with a height of $2.0 \mathrm{~m}$, diameter of $200 \mathrm{~mm}$ and effective volume of $45 \mathrm{~L}$. The scheme of the reactor is shown in Figure 1. It is filled with QTL-80S suspended spherical media and the filling ratio is 35\%. Parameters of the media are listed in Table 1. 
Table 1. Parameters of QTL-80S spherical suspension media. Item

$\begin{array}{ll}\text { Material } & \text { plastics } \\ \text { Diameter } / \mathrm{mm} & 80 \\ \text { Specific density } / \mathrm{g} \cdot \mathrm{cm}^{-3} & 0.92 \\ \text { Specific surface } / \mathrm{m}^{2} \cdot \mathrm{m}^{-3} & 800 \\ \text { Void ratio/\% } & \geq 97\end{array}$

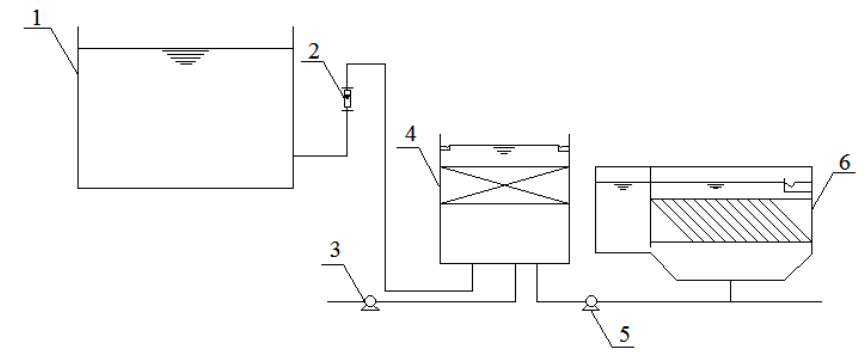

* 1 water tank 2 rotameter 3 air pump 4 hybrid biological reactor 5 sludge return pump 6 lamellae settling tank.

Figure 1. The scheme of the reactor.

Sodium bicarbonate was added into the raw water for adjusting the $\mathrm{pH}$ and it was also a carbon source for nitrifying bacteria.

The media suspended in the reactor and moved with the turbulent flow stirred by the aeration. This is benefit for the substrate degradation ability of the bio-film grew on the outer part of the spherical media. Since the hydraulic shear stress forces the bio-film a thin membrane so that the outside aerobic layer is thicker than the underlying anaerobic layer. The inner part of each spherical media is stuffed with entangled plastic thread which has a huge specific surface and is slightly washed by the water flow. There is also great amount of bio-film grows on its surface and is not prone to detach from the media thank for the relatively stable hydraulic condition.

Experimental conditions. This experiment was divided into two stages, start-up period and regular period. At the beginning, active sludge has been added in raw water for sludge acclimation and bio-film formation. After a week, the bio-film was formed on the media. And then the flow rate was increased. The operation parameters of the hybrid biological reactor are shown in the Table 2.

Table 2. Operation parameters of the hybrid biological reactor.

$\begin{array}{ll}\text { Item } & \text { Quantity } \\ \text { Effective volume/L } & 45 \\ \text { Hydraulic retention time/h } & 4 \sim 5 \\ \text { Flow rate } / \mathrm{L}^{-1} \mathrm{~h}^{-1} & 10 \\ \mathrm{DO} / \mathrm{mg} \cdot \mathrm{L}^{-1} & 2 \sim 4 \\ \mathrm{Temperature} /{ }^{\circ} \mathrm{C} & 22 \sim 29 \\ \mathrm{pH} & 7 \sim 8 \\ \mathrm{Bio}-\mathrm{film} \text { concentra- } & 1400 \sim 2100 \\ \text { tion } / \mathrm{mg} \cdot \mathrm{L}^{-1} & 1500 \sim 2500 \\ \text { MLSS } / \mathrm{mg}^{-1} \mathrm{~L}^{-1} & \end{array}$

Seed sludge.A barrel of RAS of a WWTP in Taiyuan which adopts AB process was taken as seed sludge and the sludge was capable of nitrification.

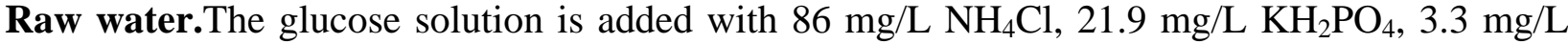
$\mathrm{MgSO}_{4} \cdot 7 \mathrm{H}_{2} \mathrm{O}, 5 \mathrm{mg} / \mathrm{L}$ trace element mixes. The constituents of trace element mixes are $50 \mathrm{mg} / \mathrm{L}$ EDTA, $2.2 \mathrm{mg} / \mathrm{L} \mathrm{ZnSO}_{4} \cdot 7 \mathrm{H}_{2} \mathrm{O}, 5.54 \mathrm{mg} / \mathrm{L} \mathrm{CaCl}_{2} \cdot 2 \mathrm{H}_{2} \mathrm{O}, 1.57 \mathrm{mg} / \mathrm{L} \mathrm{CuSO}_{4} \cdot 5 \mathrm{H}_{2} \mathrm{O}$. 
Analysis methods.The analysis methods used in this experiment are based on water and wastewater monitoring analysis method (the fourth edition) written by the editorial board of China's EPA.

(1)Water quality analysis

COD: fast digestion spectrophotometric method; $\mathrm{NH}_{3}-\mathrm{N}$ : Nessler's reagent spectrophotometry; $\mathrm{NO}_{3}-\mathrm{N}$ : Thymol spectrophotometer; DO: JENCO-9173 dissolved oxygen meter; pH: PHS-2CW acidometer; MLSS: gravimetric method.

(2)Bio-film quantity analysis

Caustic washing method: Take a certain amount of media coated with bio-film from the running reactor and put it into oven to be dried for 2 hours. Then the dried media were cooled to the room temperature in a dryer. Its weight is $\mathrm{W}_{1}$. After that, the media were heated in $2 \% \mathrm{NaOH}$ solution and stirred to strip and dissolve all the attached bio-film on the media surface. Again, the stripped media were rinsed with fresh water and put into oven to be dried for 2 hours and cooled to the room temperature in a dryer. Its weight is $\mathrm{W}_{2}$. The total biomass in the reactor is $\mathrm{W}$.

$W=\left[\frac{\left(W_{1}-W_{2}\right)}{V_{0}}\right] V$

where $\mathrm{V}_{0}=$ volume of sample media; $\mathrm{V}=$ total volume of media in the reactor.

\section{Results and discussions}

The removal effect of organic matter.The COD of influent, effluent and its removal rate are shown in Figure 2. When the influent COD was between $306.8 \mathrm{mg} / \mathrm{L} \sim 1220.6 \mathrm{mg} / \mathrm{L}$, the effluent COD was between $4.1 \mathrm{mg} / \mathrm{L} \sim 77.3 \mathrm{mg} / \mathrm{L}$ and the COD removal rate was above $90 \%$. The results indicated that the COD removal rate of the hybrid biological reactor is high and stable. The hybrid biological reactor has better adaptability to the shocking loads of influent water quality and higher organic matter removal capability compared with the previous experiments. Unfortunately, sludge bulking occurred on around 38th day when $\mathrm{C} / \mathrm{N}$ was 30 (shown in Figure 5).

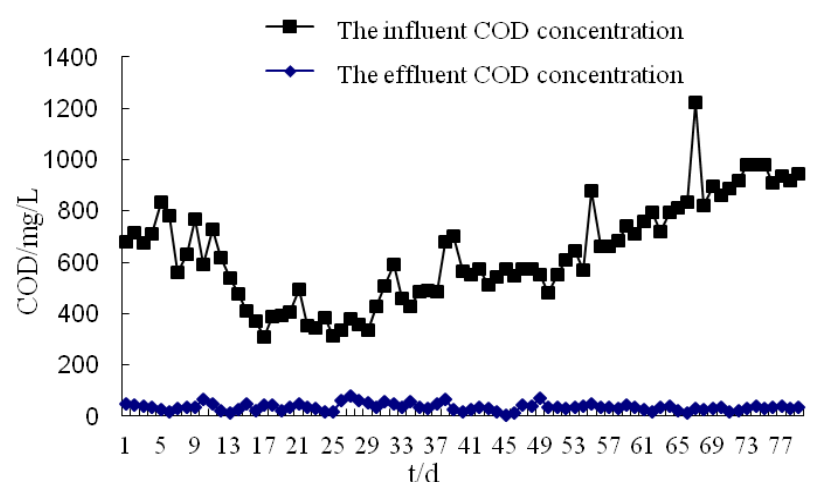

Figure 2. Variations of influent, effluent and COD removal rate .

The removal effect of $\mathbf{N H}_{3}-\mathbf{N}$.Variations of the influent and effluent $\mathrm{NH}_{3}-\mathrm{N}$ concentration are shown in Figure 3. When the influent $\mathrm{NH}_{3}-\mathrm{N}$ was between $12.134 \mathrm{mg} / \mathrm{L} \sim 38.732 \mathrm{mg} / \mathrm{L}$, the effluent $\mathrm{NH}_{3}-\mathrm{N}$ was between $0.001 \mathrm{mg} / \mathrm{L} \sim 16.025 \mathrm{mg} / \mathrm{L}$ and the $\mathrm{NH}_{3}-\mathrm{N}$ removal rate was $86.4 \%$ on average and mostly above $92 \%$. 


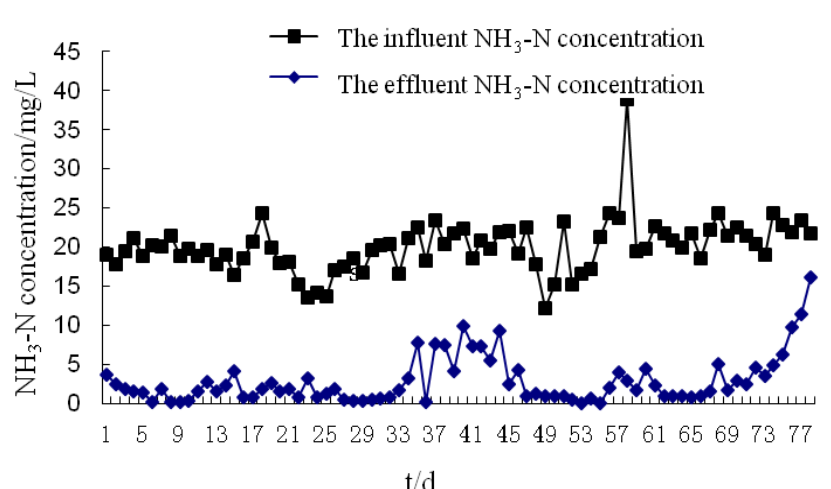

Figure 3. Variations of the influent and effluent $\mathrm{NH}_{3}-\mathrm{N}$ concentration.

Since the nitrifying bacteria which have relatively long generation time could grow on the media and were not impacted by the SRT of the activated sludge therefore the $\mathrm{NH}_{3}-\mathrm{N}$ removal efficiency was high in the hybrid biological reactor. With the increase of the $\mathrm{C} / \mathrm{N}$, the $\mathrm{NH}_{3}-\mathrm{N}$ removal rate kept high but the $\mathrm{NO}_{3}-\mathrm{N}$ concentration in the effluent was decreasing and eventually tended to be 0 $\mathrm{mg} / \mathrm{L}$.

With increasing $\mathrm{C} / \mathrm{N}$, the heterotrophic bacteria propagated and dominate not only in the active sludge but also on the bio-film. Nitrifying bacteria receded to the inner part of the sludge floc and the underlying layer of the bio-film. The transfer of $\mathrm{NH}_{3}-\mathrm{N}$ and the $\mathrm{O}_{2}$ to the nitrifying bacteria was restrained (Rittmann and Manem ,1992) and the nitrification decreased.

This means that more and more removed $\mathrm{NH}_{3}-\mathrm{N}$ was not nitrified to $\mathrm{NO}_{3}-\mathrm{N}$ but was directly assimilated by the heterotrophic bacteria. On the other hand, it also means that the heterotrophic bacteria are more robust than the autotrophic nitrifying bacteria especially when the influent COD concentration is high.

Figure 5 showed that sludge bulking occurred on the 38th day when $\mathrm{C} / \mathrm{N}$ was around 30 and COD-sludge load was $1.86 \mathrm{~kg} \mathrm{COD} /(\mathrm{kg} \bullet \mathrm{MLSS})$. After the increasing of sludge discharge and the adding of polyaluminium chloride, the sludge bulking was controlled. However, on the 48th day, sludge bulking occurred again when $\mathrm{C} / \mathrm{N}$ was around 35 and $\mathrm{COD}$ sludge load was $2.9 \mathrm{~kg}$ $\mathrm{COD} /(\mathrm{kg} \bullet \mathrm{MLSS})$. By this time, it could not be controlled by adjustment of sludge discharge and/or addition of polyaluminium chloride. The almost absolute assimilation of $\mathrm{NH}_{3}-\mathrm{N}$ and the following sludge bulking phenomenon suggested that the deficiency of nitrogen triggered the sludge bulking.

The effect of organic matter on $\mathbf{N O}_{3}-\mathrm{N}$. The main task of the first week was sludge acclimation and bio-film formation so the $\mathrm{NO}_{3}-\mathrm{N}$ measurement started from the 8th day. The variation of effluent $\mathrm{NO}_{3}-\mathrm{N}$ is shown in Figure 4. At the early stage,

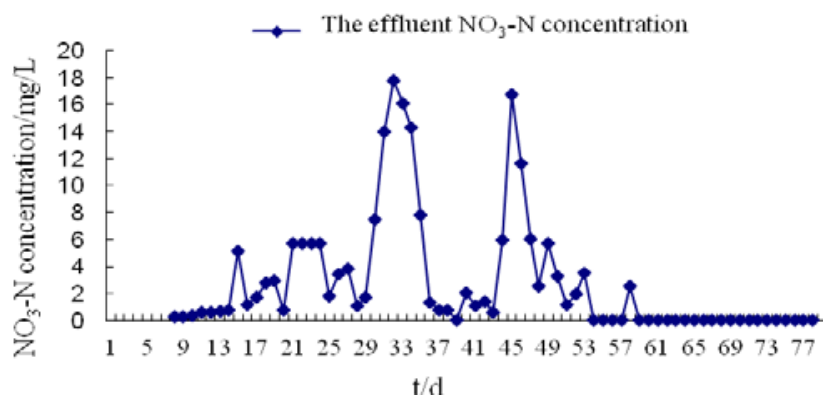

Figure 4. Variation of the effluent $\mathrm{NO}_{3}-\mathrm{N}$ concentration.

The $\mathrm{NO}_{3}-\mathrm{N}$ increased despite that the COD increased too. During the first time of the sludge bulking the $\mathrm{NH}_{3}-\mathrm{N}$ remove rate decreased abruptly and the $\mathrm{NO}_{3}-\mathrm{N}$ decreased the same time. It is worth noting that the effluent $\mathrm{NO}_{3}-\mathrm{N}$ was abnormally high in some days before sludge bulking. The 
nitrifying bacteria were then most vigorous since they transferred almost all the $\mathrm{NH}_{3}-\mathrm{N}$ into $\mathrm{NO}_{3}$ $\mathrm{N}$. Either reason that nitrifying bacteria were so competitive or the heterotrophy bacteria were so weak temporarily in these days, the extremely high efficiency of nitrification should be an early warning of the sludge bulking.

The effect of $\mathbf{C} / \mathbf{N}$ on SV of the system.The SV variations of the system are shown in Figure 5. The $\mathrm{C} / \mathrm{N}$ increased with the increase of COD in the hybrid biological reactor. When the $\mathrm{C} / \mathrm{N}$ was around 30 in the system, sludge bulking occurred mainly because of nitrogen deficiency.

At the same time, the MLSS began to decrease. This is because the lack of nitrogen leading to the suppression of anabolism of heterotrophic bacteria. With the increase of COD, the shortage of nitrogen became significant and the probability of sludge bulking became higher.

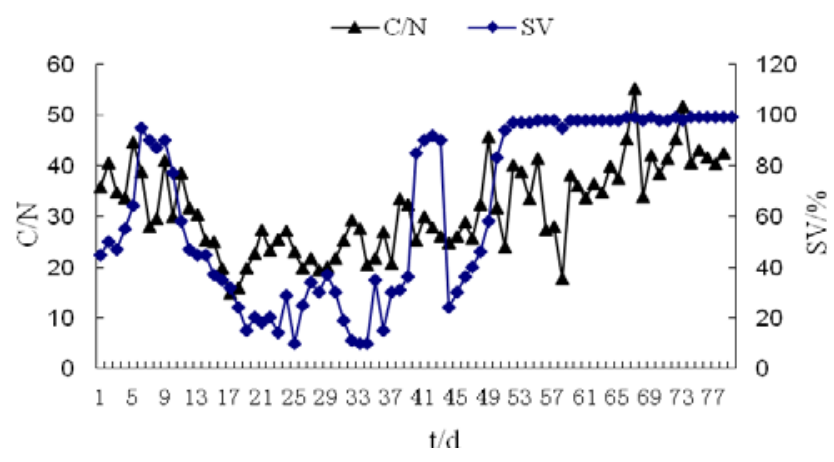

Figure 5. Variations of the SV and the $\mathrm{C} / \mathrm{N}$.

\section{Conclusions}

(1)When COD was between $306.8 \mathrm{mg} / \mathrm{L} \sim 1220.6 \mathrm{mg} / \mathrm{L}$, the removal rate of COD and $\mathrm{NH}_{3}-\mathrm{N}$ could be high and stable in which bio-film played a major role.

(2)With the increase of COD, almost all of the $\mathrm{NH}_{3}-\mathrm{N}$ in the system was directly used for the anabolism of the heterotrophic bacteria, and the effluent $\mathrm{NO}_{3}-\mathrm{N}$ gradually decreased to zero.

(3)When the $\mathrm{C} / \mathrm{N}$ is around 30, sludge bulking will occur because of nitrogen deficiency. The extremely high nitrification efficiency could be an early warning of the sludge bulking and the precursor time might be one or several days.

\section{Acknowledgements}

This research project is supported partly by Shanxi Scholarship Council of China (project: The Study of Enhanced Biological Nitrification Process), by Department of Human Resources and Social Security of Shanxi Province ,Technology Foundation for Selected Overseas Chinese Scholar (project: Study on Enhanced Biological Nitrification Process by High Concentration Nitrobacteria) and by Taiyuan Municipal Commission of Housing and Urban-rural Development (project: The Study of Advance Nitration Technology for Biological Nitrogen Removal).

The authors would like to acknowledge Yayun Yang of Taiyuan University of Technology for her analytical support and assistance in completing this work.

\section{References}

[1] Cao, B. , Wang, X.C. \& Wang, E.R. etc. 2003 Experimental Study on Urban Wastewater Treatment by Composite Bio-Reactor. Water \& Wastewater Engineering 29 (12): 28-31.

[2] Gebara, F. 1998 Activated sludge biofilm wastewater treatment system. Water Research 33(1): 230-238.

[3] Gao, C.D. , Peng, Y.Z. \& Wang, S.Y. 2002 Exploring the effects of nitrogen deficiency on the sludge bulking at different organic loading. Journal of Safety and Environment 2(3): 22-25. 
[4] Lee, H.S. , Park, S.J. \& Yoon, T.I. 2002 Wastewater treatment in a hybrid biological reactor using powdered minerals: effects of organic loading rates on COD removal and nitrification. Process Biochemistry (38): 81-88.

[5] Rittmann, B.E. \& McCarty, P.L. etc. 2002 Environment Biotechnology: Principles and Applications. Beijing: Tsinghua University Press.

[6] Wanner, J. , Kucman, K. \& Grau, R. etc. 1988 Activated Sludge Process Combined with Biofilm Cultivation. Water Research 22(2): 207-215.

[7] Wang, J.L. , Shi H.C. \& Qian, Y. 2000 Wastewater treatment in a hybrid biological reactor(HBR): effect of organic loading rates. Process Biochemistry (36): 297-303.

[8] Xie, W.P., Yang Z.H. \& Zhao, H.Z. etc. 2014 Field experiment of biological nitrogen removal by SBR. Environmental Pollution and Control 36(7):46-49

[9] Zhao, X.L. , Liang L.W. \& Hao, D. 2006 Research progress of hybrid biological reactor. Henan Chemical Industry 23 (11): 10-12. 